\title{
A Correct Valorization of Farming and Agro-Industrial Waste
}

\author{
Francesco Saverio Nesci ${ }^{1, a}$, Nicoletta Maria lellamo ${ }^{1, b}$ \\ ${ }^{1}$ Mediterranea University of Reggio Calabria - Department of Agricultural Sciences - \\ Località Feo di Vito - 89124 - Reggio Calabria - Italy \\ afrancesco.nesci@unirc.it \\ bicoletta.iellamo@unirc.it
}

Keywords: Biomass, Renewable Energies, Biochar, Carbon Credits.

\begin{abstract}
Farming and agro-industrial waste can represent a resource when destined to energy production and they can contribute to reduce greenhouse gas emission, to improve energetic efficiency and increase renewable energies.

6 stations are already working in Calabria for agro-zootechnical biomasses and agro-industrial waste transformation, in compliance with 91/676/CEE, Nitrates Directive, then D.L. 152/99 and D.M. 7 April 2006, redefined by D.M. 6-7-2012 It reduced incentives, with the aim of implementing small sized stations powered by recyclable byproducts, which are easier to manage especially in the form of consortium by medium and small sized companies that would otherwise be excluded from the market.

An appropriate use of pruning waste would also mean turning a problem into an opportunity if, instead of burning it and producing high levels of $\mathrm{CO}_{2}$ (as forbidden by D.L. "terra dei fuochi") it could be destined to produce a new kind of power source, biochar, with a carbon negative function.

Concerning the market of carbon credits derivable from pruning waste and from the production of more than $130.000 \mathrm{t}$ of biochar (which, differently from the forestry sector, hasn't been accepted in farming yet), the potential wealth on the regional territory could vary from 5 to 11 million $€$ according to the set price.

Establishing a more competitive and sustainable source of energy is one of the most important challenges that our Country has to face today. This sector plays a key role in the economic development of the Country, not only as a distinctive feature of low cost energy production, limited impact on environment and high utilization, but also as an element of growth per se, with a boost in ecologic economy thanks to a predominant use of renewable resources, recycling and curbing domestic or industrial waste, according to Green Economy parameters.
\end{abstract}

\section{Presentation}

Calabria covers a surface of $15.000 \mathrm{~km} 2$, divided into 5 provinces, 409 Municipalities, $98 \%$ of which are rural, and there are over 2.000.000 inhabitants. Calabria has a heterogeneous orographic profile, which consists of $49 \%$ hills, $42 \%$ mountains and only $9 \%$ plains.

Surplus value is $2,1 \%$ of the national wealth The percentage above is distributed as follows: agriculture 4, 1\% (national average rate 2, $0 \%$ ), industry $13,7 \%(24,6 \%)$ services $82,2 \%(73,4 \%)$. Concerning the employment rate reported in each sector, 10,6\% work in agriculture (compared to $6,8 \%$ average rate in southern Italy and 3,7\% average national rate), 1 ' $8,7 \%$ in manufacture (compared to 13,1 and $20,1 \%), 8,1 \%$ in construction $(8,1 \%$ and $7,7 \%), 72,6 \%$ in services $(72 \%$ and $68,5 \%)[1]$.

Taking into account both the employment rate and the related income, the importance of the primary sector is evident However, this is not to be ascribed to as a supposed power of the agricultural sector, which is featured by an extreme scattering of companies; on the contrary, it is due to a clear structural weakness of the other productive sectors. 
In Calabria, TAA is 706.480 hectares, while UAA is 549.253 hectares, respectively representing $4,1 \%$ and $4,3 \%$ in total at a national level, whereas active farms are 137.790, currently representing $8,5 \%$ in total at a national level (table 1) [2].

\begin{tabular}{|c|c|c|c|c|c|c|}
\hline \multirow[b]{2}{*}{$\begin{array}{c}\text { Soil } \\
\text { utilisation }\end{array}$} & \multirow{2}{*}{$\begin{array}{c}\text { Total } \\
\text { Agricultural } \\
\text { Area }\end{array}$} & \multirow{2}{*}{$\begin{array}{c}\text { Utilized } \\
\text { Agricultural } \\
\text { Area }\end{array}$} & \multicolumn{4}{|c|}{ Utilized Agricultural Area (ha) } \\
\hline & & & $\begin{array}{l}\text { woody } \\
\text { farms }\end{array}$ & $\begin{array}{c}\text { sowable } \\
\text { lands }\end{array}$ & $\begin{array}{c}\text { grasslands and } \\
\text { pasture }\end{array}$ & other \\
\hline Italy & $17.081 .099,0$ & $12.856 .047,8$ & $2.380 .768,5$ & $7.009 .310,7$ & $3.434 .073,0$ & $31.895,6$ \\
\hline Souhern Italy & $7.446 .749,8$ & $6.095 .560,2$ & $1.539 .298,1$ & $2.786 .848,0$ & $1.752 .387,0$ & $17.027,0$ \\
\hline & & & & & & \\
\hline Calabria & $706.480,0$ & $549.253,6$ & $250.983,7$ & $155.975,8$ & $140.714,9$ & $1.579,2$ \\
\hline Reggio Calabria & $149.289,5$ & $119.572,9$ & $68.782,0$ & $14.493,6$ & $36.003,2$ & 294,1 \\
\hline
\end{tabular}

Agriculture in Calabria is represented by a strongly atomized profile, with a predominance of small and micro enterprises, $86 \%$ of which are smaller than 5 hectares. It translates into objective difficulties for the market where, with a remarkable number of productive units and lack of associations, it is difficult to achieve homogeneous quality levels for the products along with appropriate quantities to fulfill the requests of the modern distribution sector and an appropriate management of farming and agro-industrial waste.

Shifting the focus of our survey from a sectorial to a territorial perspective, the strongest and most developed areas in terms of intensive and specialized farming are situated in $61 \%$ plains involving $26 \%$ of the employed workforce and producing $16 \%$ of the total regional income.

Concerning the actual usage of farm soils, woody farms are prevalent and, among them, olive cultivation is the most widespread (table 2) [2].

\begin{tabular}{|c|c|c|c|c|c|c|c|c|}
\hline cultivation & \multicolumn{2}{|c|}{ olive farming } & \multicolumn{2}{|c|}{ citrus farming } & \multicolumn{2}{|c|}{ vineyards } & \multicolumn{2}{|c|}{ fruit- bearning lands } \\
\hline territory & farms & UAA & farms & UAA & farms & UAA & farms & UAA \\
\hline Italy & 902.075 & $1.123 .329,7$ & 79.589 & $128.921,1$ & 388.881 & $664.296,2$ & 236.240 & $424.303,8$ \\
\hline Souhern Italy & 705.265 & $896.133,3$ & 77.302 & $128.084,9$ & 198.321 & $317.269,9$ & 130.212 & $188.304,2$ \\
\hline Calabria & 113.907 & $185.914,6$ & 20.974 & $35.185,3$ & 13.431 & $10.028,1$ & 11.736 & $18.532,4$ \\
\hline Reggio Calabria & 30.227 & $49.999,1$ & 10.306 & $14.853,7$ & 1.980 & $1.397,6$ & 1.684 & $2.155,1$ \\
\hline
\end{tabular}

Olive cultivation is spread over the whole regional area on 186.000 hectares of UAA distributed among 114 mila companies $(20,7 \%$ and $16,2 \%$ of southern Italy and $16,6 \%$ and $10,1 \%$ of the country). It reaches its excellence in the area of Sibari, in the upper area of Crotone and Lamezia where they have been DOP (Protected Designation of Origin) recognised. We find a different situation in the Gioia Tauro Plain which covers 30.000 hectares with over 2, 3 million plants of relevant size in terms of height and foliage, alternating, with good oil productivity, despite being particularly acidic due to the plant dimension.

The citrus sector, with 35.000 hectares of UAA distributed among 21.000 companies, (27, 5\% and $27,1 \%$ of southern Italy, and $27,3 \%$ and $26,4 \%$ of the Country), supplies $25 \%$ of the Italian total production: Calabria produces $68 \%$ of the clementines, $35 \%$ of the oranges, $100 \%$ of bergamot and $93 \%$ of cedar in Italy. In this case, each territory present a different situation as the Sibari and Lametia areas, with a strong association drive, reach excellence. On the contrary, the Piana of Gioia does not stand out in this sector as implantations are old and has a number of cultivar, as inherited by the citrus plan of the development fund for the South of Italy. Moreover, quality is not sufficient and neither is the production of juice, being them mainly intended for industrial processing. 
Viticulture only occupies 10.000 ha today, distributed among over 13.000 companies, being widespread in the Cirò area, whereas its concentration in the province of Reggio Calabria occupies 1.400 ha. Distributed among 2.000 companies. It is a sign of a strong hypertrophy, with excellent areas recognised by 2 DOP and 6 IGT awards.

Concerning zootechnics, it has always played a marginal role in regional agriculture and it is destined to fulfill local market needs, with a wider spread of sheep breeding, even free-range on hills and mountains. It is interesting to highlight the way some bigger zootechnical companies, as in the northern plains, have set stations to support zootechnics and biomass creation which, in a perspective implementation of agro-food production chains, would contribute to diversify income, support employment and become more competitive when it comes to renewable energy production in terms of both company efficiency and social welfare (table 3) [2].

\begin{tabular}{|c|c|c|c|c|c|c|c|c|}
\hline \multirow{2}{*}{\begin{tabular}{|ll} 
& farms \\
territory & \\
\end{tabular}} & \multicolumn{2}{|c|}{ beef cattle breeding } & \multicolumn{2}{|c|}{ pig farming } & \multicolumn{2}{|c|}{ sheep breeding } & \multicolumn{2}{|c|}{ goat breeding } \\
\hline & farms & UAA & farms & UAA & farms & UAA & farms & UAA \\
\hline & & & & & & & & \\
\hline Italy & 124.210 & 5.592 .700 & 26.197 & 9.331 .314 & 51.096 & 6.782 .179 & 22.759 & 861.942 \\
\hline & & & & & & & & \\
\hline Souhern Italy & 44.002 & 1.241.962 & 13.405 & |599.667 & 35.608 & 5.024 .454 & 13.154 & 659.149 \\
\hline & & & & & & & & \\
\hline Calabria & 4.885 & 98.436 & 2.193 & 51.214 & 3.896 & 246.828 & 3.001 & 133.520 \\
\hline & & & & & & & & \\
\hline Reggio Calabria & 1.375 & 17.729 & 285 & 10.425 & 1.095 & 60.369 & 1.001 & 55.021 \\
\hline
\end{tabular}

With reference to the implementation of this kind of stations, 6 of which are already working in Calabria, we find the correct framework for agro-zootechnical biomasses and agro-industrial waste transformation. This special waste (as called in D.Lgs. 152/06, art. 184, c. 3) is often greatly underestimated and treated as a nonproblem. In fact it is often solved by pouring them on soil or by direct combustion, which causes serious polluting effects due to carbon dioxide emission in the air or nitrates permeation in the soil.

The results of research carried out in this territory, where the concentration of breeding caused the highest amount of ammonium emission in the atmosphere in Europe, seriously affecting the aquifers flowing into the Adriatic Sea, highlighted the opportunities that correct implementation of the biogas production chain would bring in compliance with 91/676/CEE, Nitrates Directive, then D.L. 152/99 and D.M. 7 April 2006.

In the province of Reggio Calabria a biogas production station is working transforming agrozootechnical biomasses and agro-industrial waste. "Fattoria della Piana" in Gioia Tauro, is made of 2 hi-tech structures, with a power of 998 each, able to process sewage coming from the stables and the remaining whey from the dairy factory, as well as the manure from 20.000 birds, manure and whey from 1.000 cows and 20.000 sheep, waste from 700 hectares of citrus groves, olive pomace from 1.000 hectares of olive trees, vegetable waste coming from fruit and vegetable greenhouses and vinasse collected throughout wine processing [3].

The company is committed to collect polluting materials from its partners taking charge of transport costs and it employs these materials to produce heat and electric power, turning a problem into a resource. All the waste is collected on two sites intended for anaerobic fermentation where, thanks to mixing and heating technologies, biogas is produced with a percentage of 55\% of methane. It is burnt in the cogenerator, with a capacity of $1.000 \mathrm{~kW} / \mathrm{h}$ per machine, equal to 8.000 MkW electric power. 11\% of this production is devolved to fulfill company needs (which are more convenient than buying it) and the rest is sold. According to GSE parameters, the power produced by one machine would cover the requirements of 2.600 families. Heat power is intended for the dairy factory productive processes, with consequent savings on the purchase of fossil fuels. Waste from fermentation is used as organic manure for the pasture intended for breeding, creating a virtuous circle. 
The company implemented a herbal purification station that cleanses sewage from the dairy factory by using thousands of plants. It reduces the COD from 30.000 to 1.500 and gives clean water back to be used in further production of biomass intended for the biogas station.

The framework of incentives for biogas production stations, characterized by an all-inclusive rate of 280 euro/MWh that contributed to produced energy, was redefined by D.M. 6-7-2012 for biogas production stations. These incentives started in 2013, reducing the amount of incentives up to 180 euro/MWh, which makes it inconvenient for big stations, with the aim of implementing small sized stations powered by recyclable byproducts, which are easier to manage especially in the form of consortium by medium and small sized companies that would otherwise be excluded from the market. The farming context in Calabria, and in the province of Reggio Calabria, is featured by a strongly atomized profile and it highlights the necessity to support the implementation of such stations in order to contribute to the transformation of "environmental problems" into opportunities.

What once represented a cost to be borne is becoming an opportunity that cannot be missed. It must be taken in order to produce electric power and contribute, in compliance with the goals set by the climate-energy package (20-20-20), to the reduction of greenhouse gas emissions and to improve energetic efficiency; it is expected to increase the employment of renewable energy on the total of energetic consumption. An appropriate use of pruning waste would also mean turning a problem into an opportunity if, instead of burning it and producing high levels of $\mathrm{CO} 2$ (as forbidden by D.L. "terra dei fuochi" on environmental emergencies, having reclaim of polluted sites and the support of the law as its main pillars) it could be destined to produce a new kind of power source, biochar. Biochar has not been accepted by Italian law yet; however, it has widely been tested by the international scientific community committed to researching climate changes. Studies have analyzed the opportunity to "absorb" carbon and "steal" carbon dioxide from the soil with a carbon negative function. "Vegetable carbon" is the waste obtained from the process of transforming vegetable biomass into energy by slow combustion (pyrolysis) without oxygen. This process originates from stable humus intended for decomposition to be used as a soil conditioner. The CNR Biometeorology Institute, in Florence, pointed out how the quantity of carbon on Italian farming lands in the last century amounted to $130 \mathrm{t}$./ha of $\mathrm{C} / \mathrm{ha}$. It has currently been reduced to about $50 \%$ whereas biochar has increased to 0,7 t./year. Fertility, is this way, improved by storing up $\mathrm{CO} 2$ previously absorbed by plants and then obtained by applying pyrolysis to $2 \mathrm{t} / \mathrm{ha}$ of olive pruning waste. [4] In this regard, empirical calculations have been carried out in order to hypothesise the quantity of pruning waste and biochar potentially derivable from 185.000 ha of olive trees censed in Calabria and, consequently, the potential wealth in terms of carbon credits that could be awarded to the forestry sector (as they haven't been accepted in farming yet) (table 4) [5].

\begin{tabular}{|c|c|c|c|}
\hline \multirow{2}{*}{ PROVINCE } & $\begin{array}{c}\text { OLIVE } \\
\text { CULTIVATION } \\
\text { AREAS (HA) }\end{array}$ & $\begin{array}{c}\text { USABLE } \\
\text { PRUNING } \\
\text { WASTE (T) }\end{array}$ & $\begin{array}{c}\text { DERIVABLE } \\
\text { BIOCHAR (T) }\end{array}$ \\
\hline CS & $55.955,20$ & $111.910,40$ & $39.168,64$ \\
\hline RC & $49.999,10$ & $99.999,20$ & $34.999,10$ \\
\hline CZ & $38.470,30$ & $76.940,60$ & $26.929,21$ \\
\hline KR & $23.186,40$ & $46.372,80$ & $16.230,48$ \\
\hline VV & $18.303,60$ & $36.607,20$ & $12.812,52$ \\
\hline CALABRIA & $\mathbf{1 8 5 . 9 1 4 , 7 0}$ & $\mathbf{3 7 1 . 8 2 9 , 4 0}$ & $\mathbf{1 3 0 . 1 4 0 , 2 9}$ \\
\hline
\end{tabular}

According to the collected data that show a correspondence of $1 \mathrm{t}$. of underground biochar to 2,93 t. of carbon dioxide, the following calculations have been carried out (table 5) [5]: 


\begin{tabular}{|c|c|c|c|}
\hline $\begin{array}{c}\text { Retrieved T. } \\
\text { of } \mathbf{C O}_{\mathbf{2}}\end{array}$ & Provinces & $\begin{array}{c}\text { T. of produced } \\
\text { biochar }\end{array}$ & $\begin{array}{c}\text { Total } \\
\text { retrievable } \mathbf{C O}_{\mathbf{2}}\end{array}$ \\
\hline \multirow{4}{*}{2,93} & $\mathrm{CS}$ & $39.168,64$ & $114.764,12$ \\
\cline { 2 - 4 } & $\mathrm{RC}$ & $34.999,10$ & $102.547,36$ \\
\cline { 2 - 4 } & $\mathrm{CZ}$ & $26.929,21$ & $78.902,59$ \\
\cline { 2 - 4 } & $\mathrm{KR}$ & $16.230,48$ & $47.555,31$ \\
\cline { 2 - 4 } & $\mathrm{VV}$ & $12.812,52$ & $37.540,68$ \\
\cline { 2 - 4 } & CALABRIA & $130.139,95$ & $\mathbf{3 8 1 . 3 1 0 , 0 6}$ \\
\hline
\end{tabular}

Contextually, the $\mathrm{CO} 2$ deriving from stubble and farming waste combustion on the regional territory has been calculated in order to make a balance of useful and damaging quantities of carbon (table 6) [5].

\begin{tabular}{|c|c|c|c|c|c|}
\hline \multicolumn{6}{|c|}{$\mathrm{CO}_{2}$ EMISSION PER PROVINCE } \\
\hline & \multicolumn{2}{|c|}{ ACTIVITY DESCRIPTION } & \multicolumn{2}{|c|}{ EMISSION (T) } & \multirow{2}{*}{$\begin{array}{c}\text { WEIGHT (\%) } \\
\text { PROVINCIAL } \\
\text { PERCENTUAGE } \\
\text { ON TOTAL }\end{array}$} \\
\hline Provincia & $\begin{array}{l}\text { FARMING WASTE } \\
\text { INCENERATION (T.) }\end{array}$ & $\begin{array}{c}\text { STABLE } \\
\text { COMBUSTION (T.) }\end{array}$ & TOTAL & $\begin{array}{l}\text { TOTAL PER } \\
\text { PROVINCE }\end{array}$ & \\
\hline $\mathrm{CS}$ & $1.276,43$ & 7,408 & $1.283,84$ & $4.240,77$ & 30,3 \\
\hline$\overline{\mathrm{RC}}$ & $2.475,03$ & 0,631 & $2.475,66$ & $4.687,66$ & 52,7 \\
\hline$\overline{\mathrm{CZ}}$ & 843,09 & 2,721 & 845,811 & $2.366,12$ & 35,7 \\
\hline KR & 780,388 & 5,776 & 786,164 & $1.408,05$ & 55,8 \\
\hline$\overline{\mathrm{VV}}$ & 346,735 & 2,049 & 348,784 & $1.191,48$ & 29,3 \\
\hline CALABRIA & $5.721,67$ & $\mathbf{1 8 , 5 8 5}$ & $5.740,26$ & $13.894,08$ & \\
\hline \multicolumn{6}{|c|}{ RETRIVABLE $\mathrm{CO}_{2}$ - EMITTED $\mathrm{CO}_{2}$ BALANCE } \\
\hline Province & $\begin{array}{c}\text { TOTAL } \\
\text { RETRIEVABLE } \\
\mathrm{CO}_{2} \text { (T) } \\
\end{array}$ & \multicolumn{2}{|c|}{$\begin{array}{c}\text { TOTAL } \\
\text { EMITTED } \\
\mathrm{CO}_{2} \text { (T) }\end{array}$} & \multicolumn{2}{|c|}{$\mathrm{CO}_{2}$ CREDIT } \\
\hline $\mathrm{CS}$ & $114.764,12$ & \multicolumn{2}{|c|}{$4.240,77$} & \multicolumn{2}{|c|}{$110.523,35$} \\
\hline $\mathrm{RC}$ & $102.547,36$ & \multicolumn{2}{|c|}{$4.687,77$} & \multicolumn{2}{|c|}{97.859 .59} \\
\hline$\overline{C Z}$ & $78.902,59$ & \multicolumn{2}{|c|}{$2.366,12$} & \multicolumn{2}{|c|}{$76.536,47$} \\
\hline KR & $47.555,31$ & \multicolumn{2}{|c|}{$1.408,05$} & \multicolumn{2}{|c|}{$46.147,26$} \\
\hline $\mathrm{VV}$ & $37.540,68$ & \multicolumn{2}{|c|}{$1.191,48$} & \multicolumn{2}{|c|}{$36.349,20$} \\
\hline CALABRIA & $381.310,06$ & \multicolumn{2}{|c|}{$13.894,08$} & \multicolumn{2}{|c|}{$367.415,17$} \\
\hline
\end{tabular}

If, on the regulated market, 1 carbon credit doesn't exceed 12,00 $€ / t$. an income of $€ 4,6$ million can be foreseen. If the hammer price of $€ 30$ is applied (as occurred in the Veneto region for the forestry sector) an income of over $€ 11$ million/year can be hypothesized.

The present work is aimed at highlighting the potential wealth obtainable by appropriate use of olive ( and other farming typologies widespread in Calabria) pruning waste if turned into biochar and reused as soil conditioner.

The biochar production issue currently needs further research in order to define strong and weak points clearly; as a matter of fact, it appears to be useful at company levels as it would increase production, although testing has been carried out only on durum wheat, and it is likely to be even more important at a social level for its impact on climate change, due to its capability to absorb carbon dioxide from the soil. 
Nowadays Italy is lacking regulations for biochar usage as soil conditioner, as it is currently interpreted as simple waste. For this reason, once recognised as a resource, it is recommend that a "Definition of funding for CO2 processing at a political level" is achieved, following the model applied for the forestry sector. This would explain that this processing is not a mere attempt to compensate for excessive employment of fossil fuels.

What once represented a cost to be borne is becoming an opportunity that cannot be missed. It must be taken in order to produce electric power and contribute, in compliance with the goals set by the climate-energy package (20-20-20), to the reduction of greenhouse gas emissions.

Establishing a more competitive and sustainable source of energy is one of the most important challenges that our Country has to face today. This sector plays a key role in the economic development of the Country, not only as a distinctive feature of low cost energy production, limited impact on environment and high utilization, but also as an element of growth per se, with a boost in ecologic economy thanks to a predominant use of renewable resources, recycling and curbing domestic or industrial waste, according to Green Economy parameters.

\section{References}

[1] Banca di Italia, Note sull'andamento dell'economia della Calabria, Annate varie

[2] ISTAT, $6^{\circ}$ Censimento Generale dell'Agricoltura, (2010)

[3] F.S. Nesci, N. Sapone, Biogas agro-energetic production chain. Analysis of a case study in Calabria: The company "Fattoria della Piana", XLIII Incontro di Studi CESET, Verona (2013)

[4] F. Miglietta: Biochar: una soluzione per un'agricoltura sostenibile, ICHAR, (2013)

[5] N.M. Iellamo: Cambiamenti climatici tra adattamento e mitigazione: benefici ambientali, agronomici ed economici derivanti dall'uso del biochar e dal suo interramento nel suolo. $-\mathrm{PhD}$ Thesis in Agricultural Policy and Economy - Department of Agricultural Sciences Mediterranea University of Reggio Calabria, (2014) 